\title{
Foreword
}

\section{Betsy Myers}

In her introduction to this Handbook of Research on Gender and Leadership, Susan Madsen calls for new answers, solutions, research, and action steps when it comes to strengthening women's impact around the world. Her view, which I wholeheartedly share, is that even though women have made progress in recent years, there is still much more work that needs to be done. Indeed, according to Jason Furman, Chairman of President Obama's Council of Economic Advisers (2015), when we examine the labor forces of 24 countries, the overall proportion of working women in the United States has dropped from seventh to twentieth in a relatively short period of time. Based on Catalyst (2016) data, women today currently hold just 25.1 percent of executive and senior-level managerial positions, 19.9 percent of board seats, 9.5 percent of top-earning positions, and 4.4 percent of chief executive officer (CEO) seats. These numbers should be much higher, given that women now represent 58 percent of our college graduates.

It is true that we have more female leaders than a generation ago, but only a very small portion are sitting at the top of organizations. And, to make matters worse, the conversations we are having about gender and work today are the very same conversations we were having when I was President Clinton's advisor on women's issues in the White House during the mid-1990s. Catalyst's (2013) annual censuses of the Fortune 500 show that the gender mix at the senior levels of corporate America has changed very little in recent years. Unfortunately, this is not for lack of trying, by those with the best of intentions. However, what has historically passed for gender efforts inside corporate America has often been a series of discussions, classes, and conferences in which women find themselves talking to women. Although meaningful and productive, these strategies are often not woven into the fabric of the organization. And, on many occasions, a committed CEO and senior C-suite leaders go away believing that this support, plus periodic face-time, is sufficient.

The backdrop here, as we all know, is that the world has changed significantly. Talent is a key motivator in today's competitive global marketplace, and CEOs and savvy business leaders understand that they must have a workforce that reflects the current and future workplace and customers. They also know that the female perspective often leads to wiser decisions, and the rich relationship skills that women leaders offer frequently result in happier employees and deeper client connections. Hiring, supporting, retaining, and advancing women have become business imperatives and opportunities to be seized. The good news is that we have just about reached consensus, and the vast majority of corporate CEOs no longer ask why they should include and advance women in their organizations. So, we may understand the "why," but it is increasingly clear that what still eludes us is the "how" to include, keep, and advance women in organizations.

One of the most vital action steps is that of men mentoring women. Research shows us that men mentoring women can make all the difference to their retention and advancement. As an example, a 2014 gender parity study by Bain \& Company found that nearly half of women enter the workforce with their eye on the $\mathrm{C}$-suite, but their confidence and 
ambition levels drop 60 percent after little more than just two years on the job. One of the key findings was that marital and parental status do not significantly differ between women who aspire and those who do not. Instead, women lack the meaningful recognition, support, and mentorship from their managers necessary to shape and support their path to advancement and personal confidence. Mentorship is the essence of effective leadership, and mentoring people within an organization is a key element in the engagement and retention of top talent in today's workplace. And, because men remain the most powerful stakeholder group in most organizations, I strongly believe that men can play a powerful role in accelerating progress toward the gender equality that has eluded us for so many years.

As we work through this, it is important to remember that both women and men in organizations find themselves in a confused - and even conflicted - workplace today: confused, because gender behavior and stereotyped male-female roles in companies create uncertainty on how to be, and conflicted because we have mixed reactions, and there are judgments when we observe men acting like men, women acting like women, women acting like men, or men acting like women. We reach for programs and initiatives that might help us, and some - such as sponsorship, flexibility, and accountability - most definitely do. But corporate leaders and their teams are frustrated by the lack of gender progress as well as the gender tension (both overt and covert) that still permeates organizations. All of this drains energy and emotion - and, even worse, engagement - from our companies. So, it is no wonder that nearly two-thirds of all American workers say they are disengaged today. Reflexively promoting women into positions of greater responsibility and leadership will not immediately or necessarily boost employee engagement scores. But, as recent research from Jack Zenger and Joseph Folkman (2012) of Zenger/Folkman, a leadership development consultancy, makes clear, at every level, more women are rated by their peers, their bosses, their direct reports, and their other associates as better overall leaders than their male counterparts; and the higher the level, the wider that gap grows. These findings, as well as the insights from the contributors to this book, should be inspiration enough for us to heed Susan Madsen's urgent call for fresh approaches to women's achievement and advancement.

\section{REFERENCES}

Bain \& Company (2014). Professional women lose confidence, ambition as they reach mid-career, new Bain \& Company study finds. September 15. Retrieved from http://www.bain.com/about/press/press-releases/professional-women-lose-confidence-ambition-as-they-reach-mid-career.aspx.

Catalyst (2013). 2013 Catalyst census: Fortune 300 women board directors. December 10. Retrieved from http:// www.catalyst.org/knowledge/2013-catalyst-census-fortune-500-women-board-directors.

Catalyst (2016). Statistical overview of women in the workforce. April 6. Retrieved from http://www.catalyst.org/ knowledge/statistical-overview-women-workforce.

Council of Economic Advisors (2015). Economic Report of the President: The Annual Report of the Council of Economic Advisers. February. Retrieved from https://fraser.stlouisfed.org/docs/publications/ERP/2015_erp. pdf.

Zenger, J., and Folkman, J. (2012). A study in leadership; Women do it better than men. Retrieved from http:// www.zengerfolkman.com/media/articles/ZFCo.WP.WomenBetterThanMen.033012.pdf.

Betsy Myers, a leadership expert, author, and advocate, also speaks at and convenes workshops around the world on the changing nature of leadership and women's leadership. Her book, Take the Lead: Motivate, Inspire, and 


\section{xxiv Handbook of research on gender and leadership}

Bring Out the Best in Yourself and Everyone Around You, was released in September 2011. Her experience spans corporate, political, and higher education arenas. She is the founding director of the Center for Women and Business at Bentley University and has served as the executive director of the Center for Public Leadership at Harvard's Kennedy School of Government, USA. A senior adviser to two US presidents, the chief operating officer and chair of Women for President Obama's 2008 national presidential campaign and during the Clinton administration, she launched, and was the first director of, the White House Office for Women's Initiatives and Outreach. She also served as the director of the Office of Women's Business Ownership at the Small Business Administration (SBA). Prior to joining the Clinton administration, she spent six years building Myers Insurance and Financial Services in Los Angeles, USA, specializing in the small business and women's market. She received her bachelor's degree in business administration from the University of San Diego and her master's degree in public administration from Harvard's Kennedy School, USA, where she was also a Public Service Fellow. 